\title{
The COVID-19 Pandemic Impact on Banking Sector
}

\author{
Darjana Darjana $^{1}$ a , S.K. Wiryono ${ }^{1}$ b , D.P. Koesrindartoto ${ }^{1 ~ c ~}$ \\ 1 School of Business and Management, Bandung Institute of Technology, Indonesia \\ Keywords: credit crunch, business matching, banking sector \\ https://doi.org/10.46557/001c.29955
}

\section{Asian Economics Letters}

Vol. 3, Issue 3, 2022

This paper aims to investigate the COVID-19 pandemic's impact on the banking sector in Indonesia between 2011 and 2020. The study reveals that a credit crunch has transpired during the pandemic period. The result reveals that credit delivery decreased more during the pandemic than during the non-pandemic period. We demonstrate this effect in our examination of the pandemic's impact on credit performance. We propose business matching to overcome this dilemma.

\section{Introduction}

In this paper, we examine how the COVID-19 outbreak has affected credit performance in Indonesia. The hypothesis is that the pandemic has overwhelmed credit delivery by the banking sector. This hypothesis test is important because, during the pandemic, credit growth was negative amid the economic downturn, whereas banking deposits (i.e., third-party funds) increased. The proposed relation between the pandemic and credit performance is motivated by the credit crunch theory proposed by Bernanke \& Lown (1991). These authors define a credit crunch as a sudden sharp reduction in the availability of money or credit from banks and other lenders. This situation occurs when there is a shortage of funds in the credit market, making it difficult for borrowers to obtain financing.

This research shows the significant negative effect on the performance of banking credit due to the pandemic, utilizing a quasi-experiment to analyze the impact. Similar impact studies using quasi-experiments have been conducted on corporate performance in the energy industry and on the impact of COVID-19 testing and infection rates for the economy of Brazil, Russia, India, China, and South Africa (Dash et al., 2021).

We employ monthly data for Indonesia at the national level from 2011 to 2020 and find that the decrease in credit delivery was more significant during the pandemic than during the pre-pandemic period. These results are robust to issues related to the credit crunch phenomenon from the perspective of banking risk. Since March 2020, the intermediary function of the banking sector has been limited, contracting credit growth. The banking sector views the credit crunch as related to higher risks in the real sectors due to the uncertainty during the pandemic period. Bank lending behavior gravitates toward conservatism and risk aversion, to avoid higher credit risk. Simultaneously, bank deposits have increased, reflecting the cautious motive of depositors not spending money due to uncertain economic conditions.

With these findings, we make two contributions to the literature. First, we examine the impact of the pandemic in terms of credit performance. Second, we propose business matching as an alternative to relaxing regulations to overcome the credit crunch dilemma. The impact of the pandemic on the banking sector involves impact evaluations that are part of a broader agenda of evidence-based policymaking (Gertler et al., 2011). An impact analysis of the pandemic has also been conducted in India for the banking, insurance, and financial services industries (Ramasamy, 2020). We complement this literature by seeking an alternative route to overcome the credit crunch phenomenon instead of regulation imposed by the authorities. Our prescriptive model is intended to be used for policy recommendations in the banking sector and by the authorities.

Several studies have revealed the negative effects of the pandemic. For example, systemic risk in the financial industry has significantly increased. In the foreign exchange market, there has been a bubble of increased activity suggesting inefficiency (Narayan, 2020b). In the futures market, the relation between investor sentiment and crude oil futures prices has changed (Huang \& Zheng, 2020). In the oil market, inefficiency has become more apparent, and news on the COVID-19 pandemic and oil price has influenced oil prices when the number of infections and oil price volatility reached a certain threshold (Narayan, 2020a). In the stock market, news media speculation on the effect of

\footnotetext{
a Corresponding author: Email: darjana@sbm-itb.ac.id

b Email: sudarso_kw@sbm-itb.ac.id

c Email: deddypri@sbm-itb.ac.id
} 
the pandemic has led to negative stock returns and higher market volatility (Haldar \& Sethi, 2021).

On the other hand, empirical results show that the COVID-19 outbreak has had a significantly positive impact on increasing the innovative ability of Chinese listed companies of different scales and in selected industries (Han \& Qian, 2020). Additionally, the pandemic may have had a significant positive influence on returns in the crude oil and stock markets (Liu et al., 2020). Demographic factors and government policies are significant determinants of COVID-19 outbreaks, as opposed to socioeconomic factors such as the gross domestic product (GDP) per capita or the Human Development Index (Haldar \& Sethi, 2021).

\section{Data and Results}

\section{A. Data}

This study uses 10 years of monthly data. We have data on the nominal value of total credit, which is decomposed into credit for working capital, investment, consumption, and small and medium enterprises (SMEs). We also have credit data for selected economic sectors, namely, trading, industry, agriculture, and construction. We gather quarterly GDP data from 2011 to 2020 released in 2010 (which is also the base year) from Statistics Indonesia. We annualize the data and then convert to monthly frequency. Monthly credit data were obtained from Indonesia Financial Statistics, released by the central bank, Bank Indonesia.

Difference-in-differences (DID) analysis is one of the most widely applicable methods for impact evaluation. We apply the DID method as part of a quasi-experiment (Bertrand et al., 2002), namely, an experimental approach without experimental controls. Although alternative methods for impact evaluation can be applied, such as a regression discontinuity design and propensity matching (Khandker et al., 2010), the DID as it is commonly used in impact evaluation (Baker, 2000). The DID method requires a treatment group and a control group and a minimum of two observation periods, before and after the treatment. In this case, the treatment group involves credit performance that was affected by the pandemic. Additionally, the control group involves credit performance that was not affected by the COVID-19 pandemic. The data for the two groups data are derived from monthly banking reports.

For the DID results to be robust, we assume parallel trends. This means that both the treatment and control groups have matching linear trends, such that there is no difference in treatment. The DID method assumes that the parallel trends/slopes do not change (i.e., the trend over time is the same for both groups). This is a pseudo-experimental design because it does not differentiate between the treatment and control groups and only separates the data by period. The parallel trends of these variables in the period prior to treatment is suggestive of a counterfactual with similar trends. Likewise, these two variables (GDP and credit) pass the augmented Dickey-Fuller unit root test for stationary testing. Kahn-Lang \& Lang (2020) verify that the DID method is generally more plausible if the treatment and control groups are similar in levels to begin with, not just in trends. Our GDP and credit data are similar in levels in both periods, before and during the pandemic.

DID estimation, for example, in the two-period case, simply estimates the linear regression and the model, with the following specification:

$$
\begin{array}{r}
Y_{t}=\alpha+\beta * \text { Treated }_{t}+\gamma * \text { Post }_{t} \\
+\delta *\left(\text { Treated }^{*} \text { Post }\right)_{t}+\varepsilon_{t}
\end{array}
$$

where Treated $_{t}$ is a variable indicating whether a unit is treated or not, Post $_{t}$ is a dummy variable that indicates the post-treatment period, and $\delta$ represents a DID estimator (i.e., the change in $Y_{t}$ for treated units minus the change in $Y_{t}$ for control units).

$$
\begin{gathered}
E\left(Y_{t=1}-Y_{t=0} \mid t=0\right)=\beta \\
E\left(Y_{t=1}-Y_{t=0} \mid t=1\right)=\beta+\delta \\
\Delta Y_{t}=\delta
\end{gathered}
$$

\section{B. Results}

We collected 10-year monthly series data from 2011 to 2020 and processed them with the DID method.

\section{B.1. Total Credit}

The results in Table 1 show that all the variables are significant. The interaction coefficient is 18.87 and positive. This result indicates that after/during the COVID-19 period, the credit crunch took place with economic slowing.

In the regression, the dependent variable $Y_{t}$ is the level of the economy (GDP); the independent variable $X_{t_{-} \text {Credit }}$ represents total credit; $D_{t \_C O V I D}$ is a dummy variable that takes the value of one for the period from January to December 2020:12 (the COVID-19 pandemic period), and zero otherwise; and $D_{t_{-} C O V I D} X_{t_{-} \text {Credit }}$ is the interaction variable. The model has the following specifications:

$$
\begin{gathered}
Y_{t}=\alpha+\beta X_{t \_ \text {Credit }}+\gamma D_{t_{-} \text {Covid }}+\delta D_{t_{-} \text {Covid }} X_{t_{-} \text {Credit }} \\
Y_{2011-2019}=\alpha+\beta X_{t_{-} \text {credit }} \\
Y_{2020}=(\alpha+\gamma)+(B+\delta) X_{t \_ \text {Credit }}
\end{gathered}
$$

The estimation shows that the interaction variable $D_{t_{-} \text {COVID }} X_{t_{-} \text {Credit }}$ has a coefficient of 18.88 at the $5 \%$ significance level. The 2020 regression coefficient (gradient) of $X_{t_{-} \text {Credit }}$ is 21.55 , higher than the 2.36 from the preCOVID-19 period. This result reveals that credit performance underwent a significant change during the pandemic period in 2020 from the pre-COVID-19 period (2011-2019).

\section{B.2. Credit Decomposition}

In terms of credit decomposition, changes in the performance of working capital credit (45\% of total credit) and investment credit (30\% of the total credit) between the pre-COVID-19 and COVID-19 periods are statistically significant (see Table 2). Meanwhile, it is statistically insignificant for consumer credit and SME credit. However, the coefficients (gradients) of the four other types of credits are higher in the COVID-19 period than previously. Concurrently, non-performing loans (NPLs) increased for working capital credit and investment credit during the pandemic, but declined at the end of the period. Consumer credit NPLs eventually began to decrease in the middle of 2020. This 
Table 1. DID Estimating Result

\begin{tabular}{lccc}
\hline \multicolumn{1}{c}{$\begin{array}{c}\text { Dependent } \\
\text { Variable: Yt }\end{array}$} & $\begin{array}{c}\text { Baseline 2011:01 - } \\
2020: 12\end{array}$ & $\begin{array}{c}\text { Panel A: Pre-COVID-19 period: } \\
\text { 2011:01 - 2019:12 }\end{array}$ & $\begin{array}{c}\text { Panel B: COVID-19 period: } \\
\text { 2020:01 - 2020:12 }\end{array}$ \\
\hline $\begin{array}{l}\text { Independent } \\
\text { Variables: }\end{array}$ & Coefficients (SD) & Coefficients (SD) & Coefficients (SD) \\
\hline$X_{t_{-} \text {Credit }}$ & $2.3261^{*}$ & $2.3634^{*}$ & $2.672^{*}$ \\
$D_{t}$ COVID & $(0.0403)$ & $(0.0271)$ & $(0.0463)$ \\
$X_{t}$ Credit & - & - & $18.8765^{*}$ \\
$D_{t}$ COVID & - & & $(4.6597)$ \\
& & - & $91585.83^{*}$ \\
Constant $(\alpha)$ & $2391.79^{*}$ & $2279.06^{*}$ & $(22504.84)$ \\
$\mathrm{N}$ & $(165.7446)$ & $(106.3604)$ & $2547.846^{*}$ \\
\hline
\end{tabular}

Notes: This table presents estimating result (namely, coefficient, standard deviation (SD)) for independent variables selected from the model specification. The asterix sign (*) means that the coefficient has passed at 5\% significance level. The data are split into two samples: Panel A denotes the pre-CovID-19 sample period (2011-2019) while Panel B denotes the COVID-19 sample period (2020). Baseline column shows the regression results with total samples.

Table 2. Estimation of Credit Decomposition

\begin{tabular}{|c|c|c|c|}
\hline $\begin{array}{l}\text { Dependent } \\
\text { Variable: } Y_{t}\end{array}$ & $\begin{array}{l}\text { Baseline 2011:01 - } \\
\text { 2020:12 }\end{array}$ & $\begin{array}{l}\text { Panel A: Pre-COVID-19 period: } \\
\text { 2011:01 - 2019:12 }\end{array}$ & $\begin{array}{l}\text { Panel B: COVID-19 period: } \\
\text { 2020:01 - 2020:12 }\end{array}$ \\
\hline $\begin{array}{l}\text { Independent } \\
\text { Variables: }\end{array}$ & Coefficients (SD) & Coefficients (SD) & Coefficients (SD) \\
\hline$X_{t_{-} \text {Credit }} 1$ & $\begin{array}{l}5.3398^{*} \\
(0.0977)\end{array}$ & $\begin{array}{l}5.3223^{*} \\
(0.0766)\end{array}$ & $\begin{array}{l}22.7303^{*} \\
(0.0998)\end{array}$ \\
\hline$X_{t_{-} \text {Credit }} 2$ & $\begin{array}{l}7.9726^{*} \\
(0.1582)\end{array}$ & $\begin{array}{l}8.2706^{*} \\
(0.1217)\end{array}$ & $\begin{array}{c}41.6365^{*} \\
(0.1596)\end{array}$ \\
\hline$X_{t \_C r e d i t} 3$ & $\begin{array}{l}8.4144^{*} \\
(0.1382)\end{array}$ & $\begin{array}{l}8.6372 * \\
(0.0575)\end{array}$ & $\begin{array}{l}18.4964 \\
(0.1511)\end{array}$ \\
\hline$X_{t_{-} \text {Credit }} 4$ & $\begin{array}{l}12.9291^{*} \\
(0.2221)\end{array}$ & $\begin{array}{l}13.4112^{*} \\
(0.0984)\end{array}$ & $\begin{array}{l}14.5569 \\
(0.2392)\end{array}$ \\
\hline Constant1 & $\begin{array}{l}1779.204^{*} \\
(185.7102)\end{array}$ & $\begin{array}{l}1808.431 * \\
(139.7457)\end{array}$ & $\begin{array}{c}-41338.799 * \\
(182.1004)\end{array}$ \\
\hline Constant2 & $\begin{array}{l}3859.366^{*} \\
(162.0112)\end{array}$ & $\begin{array}{l}3642.514^{*} \\
(117.1909)\end{array}$ & $\begin{array}{l}-45923.1760^{*} \\
(153.5992)\end{array}$ \\
\hline Constant3 & $\begin{array}{l}1934.754^{*} \\
(164.3405)\end{array}$ & $\begin{array}{c}1731.067^{*} \\
(65.184)\end{array}$ & $\begin{array}{c}-14552.0630 * \\
(171.4535)\end{array}$ \\
\hline Constant4 & $\begin{array}{l}1352.609^{*} \\
(181.5038)\end{array}$ & $\begin{array}{c}1041.112^{*} \\
(76.7945)\end{array}$ & $\begin{array}{c}-907.1470^{*} \\
(186.603)\end{array}$ \\
\hline$N$ & 120 & 108 & 12 \\
\hline
\end{tabular}

Notes: This table reports estimating result (coefficient) for independent variables selected from model specification. The asterix sign $\left({ }^{*}\right)$ means that the variable has statistically passed at $5 \%$ significance level. Coefficients in Panel B consist of $D_{t_{-} C O V I D} X_{t_{-} C r e d i t}$ and $D_{t_{-} C O V I D}$ of each credit decomposition (1. Working Capital, 2. Investment, 3. Consumers, 4 . SMEs), respectively. Baseline column shows the regression results with total samples.

pattern could be due to the credit restructuring policy announced in March 2020.

\section{B.3. Credit by Economic Sector}

Regarding credit by economic sector, the primary sectors (industry, agriculture, construction) were significantly influenced by the pandemic, with the exception of trade (see Table 3).

Credit for agriculture and credit for construction have negative coefficients during the COVID-19 period. This result indicates that, even during the economic downturn, the two sectors still achieved positive performance. This can explain how the food harvesting and infrastructure devel- opment continued to function during the COVID-19 pandemic.

The coefficient for the trade sector is statistically insignificant, possibly because of the rise of the digital economy. The resiliency of the trade sector could be related to online trading activities. Data from Statistics Indonesia reveal that, during the early pandemic, around March 2020, online sales surged by $320 \%$ of total sales at the beginning of the year. The highest sales recorded is for food and beverages (480\%). The jump becomes even steeper, with online sales in April 2020 increasing by 480\% since January 2020.

Several policies were instituted by the government and the authorities to handle the credit crunch. The Ministry 
Table 3: Estimation of Credit by Economic Sectors

\begin{tabular}{|c|c|c|c|}
\hline $\begin{array}{l}\text { Dependent } \\
\text { Variable: } Y_{t}\end{array}$ & $\begin{array}{l}\text { Baseline 2011:01 - } \\
\text { 2020:12 }\end{array}$ & $\begin{array}{l}\text { Panel A: Pre-COVID-19 period: } \\
\text { 2011:01 - 2019:12 }\end{array}$ & $\begin{array}{l}\text { Panel B: COVID-19 period: } \\
\text { 2020:01 - 2020:12 }\end{array}$ \\
\hline $\begin{array}{l}\text { Independent } \\
\text { Variables }\end{array}$ & Coefficients (SD) & Coefficients (SD) & Coefficients (SD) \\
\hline$X t \_C r e d i t 1$ & $12.5433 *(0.4569)$ & $11.9326 *(0.4322)$ & $44.5463(0.4487)$ \\
\hline$X t \_C r e d i t 2$ & $13.8039 *(0.3542)$ & $13.5098 *(0.3448)$ & $45.6548 *(0.3683)$ \\
\hline$X t \_C r e d i t 3$ & $27.1966 *(0.4756)$ & $28.0318 *(0.1899)$ & $-127.3115 *(0.4409)$ \\
\hline$X t \_C r e d i t 4$ & $26.019 *(0.6808)$ & $28.5675 *(0.4854)$ & $-108.2615^{*}(0.5651)$ \\
\hline Constant1 & $\begin{array}{l}1891.366^{*} \\
(364.5463)\end{array}$ & $2237.982 *(335.6237)$ & $-28097.218 *(348.4054)$ \\
\hline Constant2 & $\begin{array}{l}2533.503^{*} \\
(241.5494)\end{array}$ & $2684.881 *(226.0487)$ & $-25316.089 *(241.4657)$ \\
\hline Constant3 & $\begin{array}{l}4628.198^{*} \\
(130.2013)\end{array}$ & $4470.399 *(48.7264)$ & $65530.419 *(113.1093)$ \\
\hline Constant4 & $\begin{array}{l}6407.774^{*} \\
(151.7185)\end{array}$ & $6052.225 *(97.3447)$ & $54750.625^{*}(113.3429)$ \\
\hline $\mathrm{N}$ & 120 & 108 & 12 \\
\hline
\end{tabular}

Notes: This table reports estimating result (coefficient) for independent variables selected from model specification. The asterix sign $(*)$ means that the variable has statistically passed at $5 \%$ significance level. Coefficients in Panel B consist of $D_{t_{-} \text {Covid }} X_{t_{-} \text {Credit }}$ and $D_{t_{-} \text {Covid }}$ of each credit of economic sectors (1. Trade, 2. Industry, 3. Agriculture, 4. Construction), respectively. Baseline column shows the regression results with total samples.

of Finance released approximately INR 700 trillion (around USD 460 billion) in economic recovery funds as part of fiscal policy to boost the economy, especially among lower-income households. Bank Indonesia lowered the policy rate by 150 basis points since early 2020, to $3.50 \%$, the lowest rate in Indonesian economic history. Correspondingly, Bank Indonesia lowered banking reserves and implemented loan to value as amacroprudential policy in the transportation vehicle and property sectors. The Financial Services Authority of Indonesia introduced a relaxation policy for credit restructuring (regulation \#11/POJK.03/2020 about the National Economic Stimulus as a Countercyclical Policy Impact of the Spread of COVID-19) to help debtors avoid credit default.

Generally, banking performance since December 2020 remained economically sound, according to several indicators of the Financial Services Authority, such as the capital adequacy ratio (23.81\%), liquid assets to third-party funds $(31.67 \%)$, return on assets $(1.59 \%)$, net interest margin $(4.32 \%)$, and gross NPLs (3.06\%). However, the effect of the relaxation of credit restructuring increased banking loans at risk (LAR). ${ }^{1}$ Bank reports at the end of 2020 stated that, at the national level, the banking LAR stood at 25\%, and the commercial banks categories based on business activity (BUKU) 4th group (with core capital above IDR 30 trillion) held the largest LAR position, with a rate approaching $27 \%$. This means banks were confronting more risks in terms of their intermediary function.

To keep their profit, rather than disburse credit, banks placed more of their large third-party funds into government bonds. The amount of government bonds held by banks increased particularly during the pandemic period, with $136.61 \%$ (year-on-year) growth. This was due to the government bond yield $(6.17 \%$ at the end of 2020 , Ministry of Finance (MOF)), which remained attractive for banks compared to other placements.

The collaboration policies among the authorities on the demand side aim to increase public purchasing power for real sector activities. Simultaneously, policies on the supply side support bank liquidity and decrease credit risk to improve banking's intermediary function. On the practical side, business matching for financing has been proposed for SMEs, in collaboration with the representative office of the central bank to integrate the real and financial sectors, particularly the banking sector. Communication and relationship building between the real and financial sectors would be an alternative means to help overcome the credit crunch.

Productive and safe sectors have been identified, such as the information and communications and agricultural sectors. The matrix in Table 4 was developed from a catalog of pandemic spread risks and the 2020 annual growth of each economic sector. Productive and safe sectors are low risk and have strong prospects in terms of growth. The economic sector could be a driving factor in the current economic recovery, such that financial institutions could be persuaded to finance the productive and safe sectors.

\section{Conclusion}

This research shows that the COVID-19 outbreak has affected the banking sector through declining credit delivery to the real sectors. In terms of nominal value, total credit 


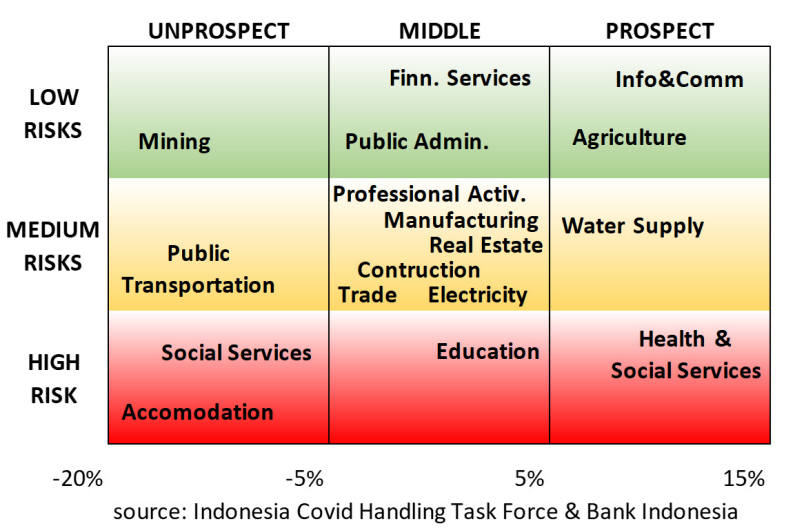

Table 4. Productive and Safe Economic Sectors

Notes: This matrix in row the economic sectors categorized into three levels of risk, derived from the Indonesian COVID Handling Task Force. The prospect of each economic sector is derived from the annual growth figures from Bank Indonesia.

decreased in parallel with economic deceleration during the pandemic. Working capital credit and investment credit were influenced by the pandemic, but not consumption credit or SME credit. In the economic sector, the credit of the industry, agriculture, and construction were affected by the COVID-19 outbreak, but not the credit of the trade.

This research contributes to the assessment of the existence of a credit crunch during the COVID-19 pandemic by measuring the impact of the pandemic on the banking sector. Alongside the policy of credit relaxation, business matching is proposed to overcome the credit crunch. Banks can disburse credit to the proposed productive and safe economic sectors. In order to not remain just a concept, future research could seek innovative business models to implement the financing to overcome the credit crunch.

\section{Acknowledgement}

We would like to thank and send our appreciation to the editors of the Asian Economics Letters journal particularly Dr. Susan Sharma, Managing Editor and the reviewers who have supported us by sending inputs and comments to improve this research. 


\section{References}

Baker, J. L. (2000). Evaluating the impact of development projects on poverty: A Handbook for Practitioners. The World Bank. https://doi.org/10.1596/0-8213-4697-0

Bernanke, B., \& Lown, C. S. (1991). Credit crunch. Brookings Papers on Economic Activity, 22(2), 205-248. https://doi.org/10.2307/2534592

Bertrand, M., Duflo, E., \& Mullainathan, S. (2002). How much should we trust differences-in-differences estimates?. NBER Working Paper. https://doi.org/10.3 $\underline{386 / \mathrm{w} 8841}$

Dash, D. P., Sethi, N., \& Dash, A. K. (2021). Infectious disease, human capital, and the BRICS economy in the time of COVID-19. MethodsX, 8, 101202. https://d oi.org/10.1016/j.mex.2020.101202

Gertler, P. J., Martinez, S., Premand, P., Rawlings, L. B., \& Vermeersch, C. M. J. (2011). Impact evaluation in practice. World Bank.

Haldar, A., \& Sethi, N. (2021). The news affects Covid-19 on the global financial market volatility. Bulletin of Monetary Economics and Banking, Special Issue 2021, 33-58.

Han, H., \& Qian, Y. (2020). Did Enterprises' Innovation Ability Increase During the COVID-19 Pandemic? Evidence From Chinese Listed Companies. Asian Economics Letters, 1(3), 18072. https://doi.org/10.465 $\underline{57 / 001 c .18072}$
Huang, W., \& Zheng, Y. (2020). COVID-19: Structural changes in the relationship between investor sentiment and crude oil futures price. Energy Research Letters, 1(2), 13685. https://doi.org/10.4655 7/001c.13685

Kahn-Lang, A., \& Lang, K. (2020). The promise and pitfalls of differences-in-differences: reflections on 16 and pregnant and other applications. Journal of Business and Economic Statistics, 38(3), 613-620. http s://doi.org/10.1080/07350015.2018.1546591

Khandker, S. R., Koolwal, G. B., \& Samad, H. A. (2010). Handbook on impact evaluation: Quantitative methods and practices. World Bank.

Liu, L., Wang, E. Z., \& Lee, C. C. (2020). Impact of the COVID-19 pandemic on the crude oil and stock markets in the US: A time-varying analysis. Energy Research Letters, 1(1), 13154. https://doi.org/10.4655 7/001c.13154

Narayan, P. K. (2020a). Oil price news and COVID-19-Is there any connection? Energy Research Letters, 1(1), 13176. https://doi.org/10.46557/001c.13176

Narayan, P. K. (2020b). Did bubble activity intensify during COVID-19. Asian Economics Letters, 1(2), 17654. https://doi.org/10.46557/001c.17654

Ramasamy, K. (2020). Impact analysis in banking, insurance and financial services industry due to covid-19 pandemic. Pramana Research Journal, 10, 8,19-29. 